\title{
Using life cycle assessment for municipal solid waste management in Tehran Municipality Region 20
}

\author{
Salar Omid ${ }^{1}$, Zahra Derakhshan ${ }^{2}$, Mehdi Mokhtari ${ }^{3 *}$ \\ ${ }^{1}$ MSc Student of Environmental Pollutions, Science and Research Unit, Department of Natural Resources-Environmental Engineering- \\ Pollutions, Yazd Branch, Islamic Azad University, Yazd, Iran \\ ${ }^{2} \mathrm{PhD}$ Student of Environmental Health Engineering, Environmental Science and Technology Research Center, Department of \\ Environmental Health Engineering, School of Public Health, Shahid Sadoughi University of Medical Sciences, Yazd, Iran \\ ${ }^{3}$ Assistant Professor of Environmental Health Engineering, Environmental Science and Technology Research Center, Department of \\ Environmental Health Engineering, School of Public Health, Shahid Sadoughi University of Medical Sciences, Yazd, Iran
}

\begin{abstract}
Background: Due to the lack of a proper waste management system, Tehran Municipality Region 20 is facing economic and environmental problems such as the high costs of a disposal system and source pollution. Life cycle assessment (LCA) is a method for collecting and evaluating the inputs, outputs, and potential environmental impacts of a product system throughout its life cycle. The current study purposed to provide a stable and optimized system of solid waste management in Tehran Municipality Region 20.

Methods: The LCA method was used to evaluate various scenarios and compare the effects on environmental aspects of management systems. Four scenarios were defined based on existing and possible future waste management systems for this region. These scenarios were considered with different percentages for source separation, composting, recycling, and energy recovery.

Results: Based on the results of this study, Scenario 4 (source separation [14\%] + composting [30\%] + municipal recycling facility $[\mathrm{MRF}][20 \%]+$ energy recovery $[10 \%]+$ landfilling $[26 \%]$ ) was found to be the option with the minimum environmental impact. In the absence of government support and sufficient funds for establishing energy recovery facilities, the third scenario (source separation [14\%] + composting [30\%] + MRF [20\%] + landfilling [36\%]) is recommended.

Conclusion: The results acquired from this investigation will confirm the belief that LCA as an environmental device may be successfully used in an integrated solid waste management system (ISWMS) as a support tool for decision-making.

Keywords: Municipal solid waste management, Life cycle assessment, Waste management, Tehran

Citation: Omid S, Derakhshan Z, Mokhtari M. Using life cycle assessment for municipal solid waste management in Tehran Municipality Region 20. Environmental Health Engineering and Management Journal 2017; 4(2): 123-129. doi: 10.15171/EHEM.2017.17.
\end{abstract}

\section{Article History:}

Received: 28 December 2016 Accepted: 28 February 2017 ePublished: 25 March 2017

\section{Introduction}

Life cycle assessment (LCA) is a methodology for examining environmental impacts of a product, process, or service "from cradle to grave," i.e. from the production of raw materials to the ultimate disposal of wastes $(1,2)$. The information obtained from an LCA study can be helpful in identifying solutions and optimizing the environmental impact of the product. The results will further be beneficial in terms of decision-making, organizing, and both governmental and nongovernmental planning $(3,4)$. One of the most important capabilities of LCA is helping decision-makers choose the best option from among two or more options by comparing the environmental impacts of products, processes, and services $(5,6)$. This feature is particularly important in studies employing the comparative view and choosing the best option from among solid waste disposal options $(7,8)$. An LCA study includes four steps: goal, scope definition, life cycle inventory (LCI) impact assessment, and interpretation. These steps are continuously linked (9) (Figure 1). In some cases, the intended purpose of an LCA study is only to collect, analyze, and interpret data. This kind of LCA is the same as the method of LCA with the only difference being in the third phase of the study, which is the impact assessment.

LCA has been used as an effective environmental management tool in many studies to compare the environmental impacts of different automobiles (10), to compare the environmental impacts of using key detergent builder systems (11), to decrease the volatile organic compounds (VOCs) content of paint in the paint industry (12), to reduce the environmental burdens of 


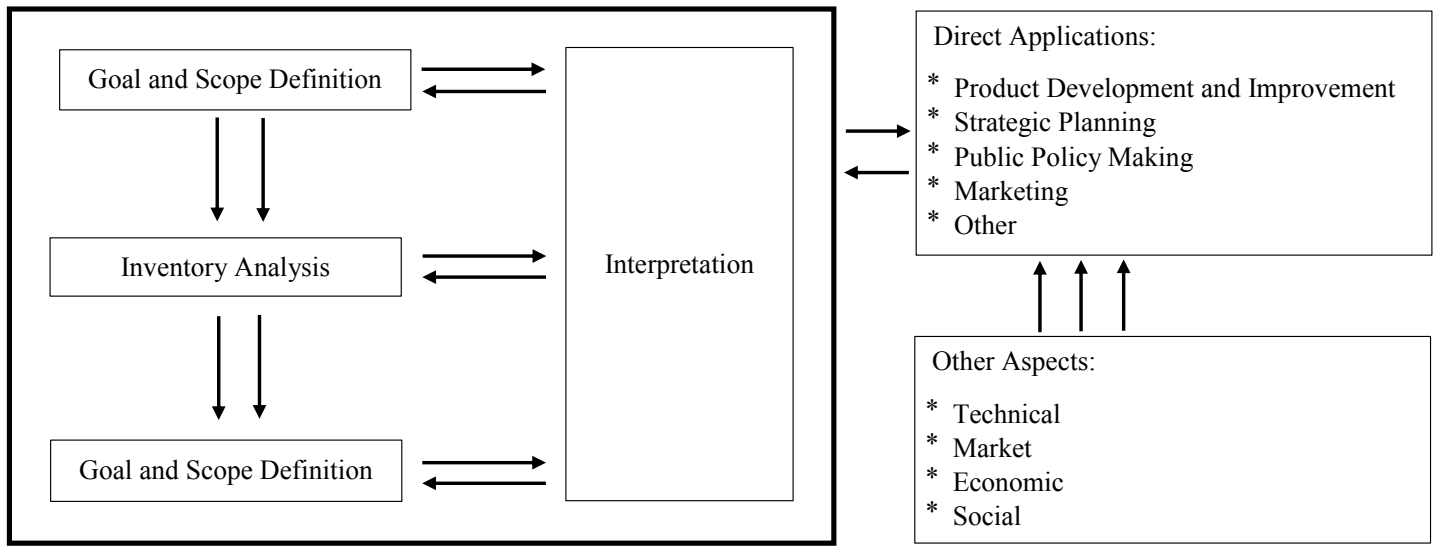

Figure 1. Life cycle assessment.

used automotive batteries (13), to compare 2 groundwater treatment schemes for removing hardness and color (14), to compare various forestry activities such as cutting and shelterwood cutting in forest management systems (15), to assess different possible scenarios for the treatment of municipal wastewater (16), to examine the potential environmental and human health implications of different contaminated site remediation options (17), and so on. Shahr-e-Rey Tehran Municipality Region 20 has 7 zones. At present 92000 families live in this region. According to recent studies conducted by the Waste Management Organization of Tehran in 2012, 298 tons of waste is being generated on a daily basis in Shahr-e-Rey. Currently, 9\% of the generated waste is separated at source and 15\% of organic components are transferred to the composting plant. In recent years, the lack of a proper management system has presented the region with many problems. Although many studies have been conducted in the field of solid waste management systems in Iran (18-23), very few works have examined the application of LCA in decision-making about solid waste management strategies $(7,18,24,25)$. In recent years this approach has been used in several countries to assess waste management strategies (16,26-37).

The main objective of the present study was to apply LCA to compare different solid waste management scenarios produced in Shahr-e-Rey in terms of environmental aspects. The results of this study can be used for other cities in developing countries that have similar municipal waste compounds.

\section{Methods}

Study area

Region 20 (Shahr-e-Rey) is in southern Tehran. It has an area of $22 \mathrm{~km}^{2}$ in the metropolitan area, $178 \mathrm{~km}^{2}$ limits at 35 degrees 36 minutes' north latitude and 51 degrees 26 minutes' east longitude, and a municipal population of 453740 . The amount of waste generated differs greatly among seasons, but reaches its maximum value in summer because of the presence of pilgrims. It is estimated that $6 \%$ of materials are disposed of in the landfill, $54 \%$ is paper and cardboard, $10 \%$ is plastic, $11 \%$ is metal, $10 \%$ is glass, and textiles make up 9\% (Table 1).

In the current study, LCA was applied to consider different waste management scenarios from an environmental point of view in order to present an optimal solid waste management system used to research information related to life cycle. The life cycle evaluation steps are described under the Integrated Waste Management (IWM) model advanced by Doughall (38). The model was designed as a choice-guide tool for waste managers in each industry and related authorities who want to decide between numerous options for waste management. This model is utilized in Europe, South America, and Asia to assist the design or optimization of both local and neighborhood waste management systems (38). The IWM model shows the environmental interventions associated with a waste disposal system. To carry out the LCA inventory of the landfill, all environmental masses were taken into consideration as well as those corresponding to the effluents from the plant itself. This input information must be transmitted to the following process in the landfill and to the by-products obtained there (gas, electrical energy, etc). This is done by means of a vector that contains all the information about all the possible types of pollution. Each product or process flow has an associated vector with all the information on the pollution generated during the entire life cycle. This eco-vector is a multidimensional vector in which each dimension corresponds to a selected pollutant (1).

\section{Scope and goal definition}

Three exceptional situations for municipal solid waste management systems (MSWMSs) that consist of special

Table 1. Municipal solid waste composition in Shahr-e-Ray (kg/y)

\begin{tabular}{ll}
\hline Waste & Mean (SD) \\
\hline Plastic & $33711.23 \pm 393.7$ \\
Paper and Cardboard & $182040.62 \pm 747.5$ \\
Metals & $37082.35 \pm 252.8$ \\
Textiles & $30340.10 \pm 253.0$ \\
Glass & $33711.23 \pm 222.3$ \\
Residuals & $20226.74 \pm 132.4$ \\
Total & $337112.27 \pm 825.1$ \\
\hline
\end{tabular}


MSW processing and/or disposal methods were developed and then compared in terms of their environmental burdens and total fuel consumption. In order to achieve environmental sustainability the MSWMSs were compared in an LCA context which considered the following components source separation recycling composting material recovery and energy recovery.

Functional unit and system boundaries

The functional unit used in the scenarios was defined as the amount of municipal solid waste generated in Region 20 of Tehran in one year. The system boundaries selected for the life cycle of solid waste were defined as the moment materials ceased to have value and became waste and when waste became inert landfill material, was converted into air and/or water emissions, or regained some value (Figure 2).

\section{Scenarios}

In order to achieve the optimal system of waste management in Shahr-e-Rey, four management scenarios were proposed. The first scenario was considered the basic method of waste management, and future scenarios were developed based on the current situation of the solid waste management of Shahr-e-Rey, plans of the waste management organization to improve the management system, and international standards of solid waste management.

Scenario 1: In this scenario, all generated wastes collected either manually or automatically were sent to the transfer station and then to the landfill site; sometimes, they were transferred directly to the landfill.

Scenario 2: The second scenario was defined based on the current situation of waste management in the studied area. Nine percent of the waste was separated at the source by citizens, $15 \%$ was organic waste and was sent to a composting facility to produce compost, $16 \%$ was transferred to the material recovery facility (MRF) to separate recyclable materials, and the remaining $60 \%$ was transferred to the landfill site for final disposal.

Scenario 3: Based on the organization's future plans to improve management methods, the third scenario was determined to be $14 \%$ source separation, $30 \%$ composting, $20 \%$ recycling, and 36\% landfilling.

Scenario 4: Scenario 4 differs from Scenario 3 in that 10\% energy recovery through an energy recovery facility was added to other management options. Only $26 \%$ of the remaining wastes were landfilled. Figure 3 illustrates the mentioned scenarios.

\section{Life cycle inventory}

The data in this study was obtained mainly from the information available from the Waste Management Organization of Shahr-e-Rey, related literature, and field studies and included waste characteristics and composition by weight waste flow, waste collection transfer and transportation, amount of recycling and composting, and operational data from the transfer station and landfill site. The data was collected to calculate the level of emissions to air and water as well as energy consumption.

The IWM model was run for each scenario. The outcomes defined the environmental elements of those eventualities. The significance of every effect in inventoried values was normalized based on the rate of controlled waste in each scenario and opportunity. These values were then expanded using the characterizing factors to calculate the inventoried values in every significant executed effect in line with the unit. The next stage, achieved indicators in each class, were multiplied by the proportional weight of that class to put the additive indictors together. Based on the equivalent unit or ecological indicator, environmental load of each class was calculated. At the time of the study, $337112.3 \mathrm{~kg}$ of waste were being generated annually in Shahr-e-Rey. Approximately $9 \%$ of the generated waste was collected separately, not sent to landfills, but sold to various companies and factories as raw materials. In the second scenario, $3 \%$ of source separation was added to the waste management system. In the last scenario, an energy

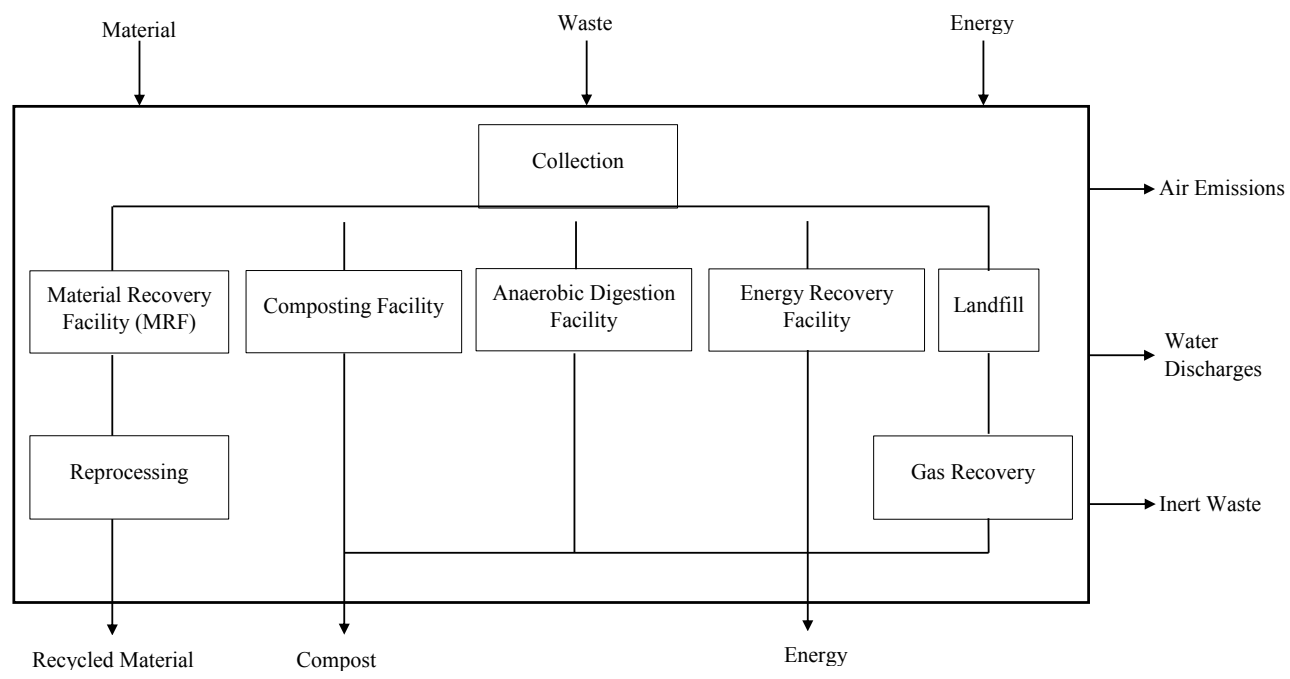

Figure 2. Boundary definition. 


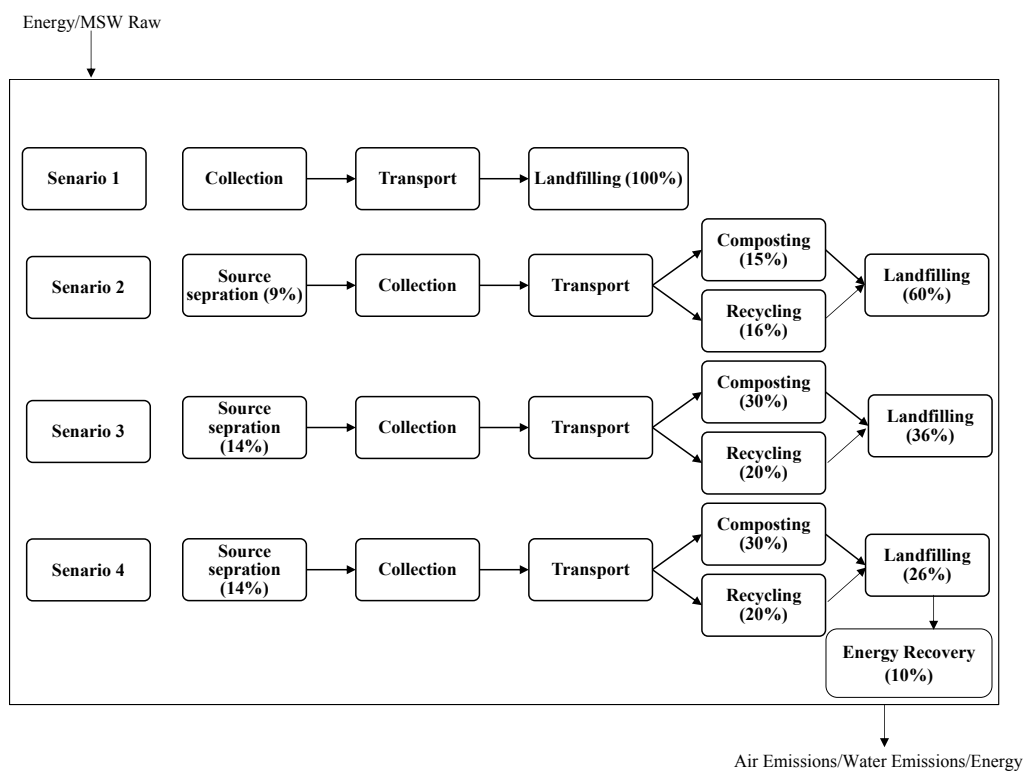

Figure 3. Four scenarios of MSWMSs used in this study.

recovery facility was considered near the landfill site. The incineration method was not included in the waste management system because of the resulting high levels of pollution generated and high costs.

\section{Results}

Comparison of scenarios in terms of energy consumption The results of the current study demonstrate that energy consumption in Scenario 1 was not compensated for in any way due to the lack of waste processing and byproduct production (Tables 1 and 2). Therefore, gross and net energy consumption values were equal. In the second scenario, source separation recycling and composting were included in the management plan and resulted in a reduction in the amount of waste disposal as well as energy consumption in landfilling. This is in contrast with energy consumption in recycling and composting which was increased. In this scenario, more energy was compensated for through the production of new materials by recycling, replacing the produced material with raw material consumed in the life cycle, and also by composting and producing other byproducts. However, this replacement rate was not sufficient to cover the total energy consumption; therefore, this scenario had a positive net energy consumption value and could not compensate for part of the energy consumed in reprocessing the recycled materials. In the third scenario, the amounts of source separation, MRF, and composting were increased. Although the amount of energy consumed in recycling and composting was higher compared with the second scenario, less energy was consumed for reprocessing the recycled materials; therefore, most of the energy was compensated for in this scenario, and net energy consumption was decreased. This means that the increase in the amount of recycling and composting solid waste had a positive effect on the life cycle. Energy recovery was added to the waste management plan in the fourth scenario. Facilities for energy recovery from waste require energy; however, the production of energy resulted in a reduction in net energy consumption.

\section{Discussion}

Comparison of scenarios in terms of greenhouse gases Table 3 shows the comparison of net emissions of the four studied scenarios. As indicated in the table, greenhouse gas emissions were decreased from the first scenario to the last one. This reduction in the amount of emissions confirmed that the scenarios were being optimized. Negative numbers indicated the emissions decreased because of facilities recycling metals and reprocessing other materials.

Comparison of scenarios in terms of acid gases Like greenhouse gases, acid gases followed the declining trend; however, the reduction in the emission of this group was greater than that of greenhouse gas emissions. Recycling, composting, and energy recovery facilities had significant effects on reducing emissions, particularly $\mathrm{HCl}$.

Comparison of scenarios in terms of smog precursors The analysis of smog precursors in the different scenarios demonstrated that Scenario 2 had the greatest impacts on reducing smog emissions; this further indicated that the establishment of MRF and composting facilities were significant in decreasing such gas emissions. Conversely, the increase in recycling and composting in Scenario 3 caused an increase in smog emissions; thus, a certain amount of recycling and composting reduced smog emissions. In Scenario 4, the addition of an energy recovery option to the management system led to a reduction in $\mathrm{NO}_{x}$ and $\mathrm{PM}$. 
Comparison of scenarios in terms of heavy metals and organics

As Table 2 indicates, the establishment of MRF and energy from waste (EFW) facilities had no positive effect on reducing the emission of heavy metals or organics, while the emission of heavy metals and organics was decreased, like the previous group of gases. All in all, the fourth scenario was more optimized than the first one. Although Scenario 4 resulted in the release of larger amounts of heavy metals and organics into the air, this could be controlled by proper management.

Abduli et al (18) examined the operation and preservation activities for landfilling and composting in Tehran. They concluded that there were contrasting environmental impacts between the cutting-edge MSW strategies of landfill and composting-plus-landfill. LCA was used to compare these scenarios for MSW, and the results confirmed that the composting-plus-landfill scenario caused less damage to human health than the landfill scenario. Municipal waste management scenarios, such as open dumping, composting, anaerobic digestion, and pyrolysis-gasification, were compared using the Center for Environmental Studies method. The impact assessment categories that were considered were emission of greenhouse gases, ozone layer depletion, acidification, eutrophication, ecotoxicity, human toxicity, and summer smog. Mali and Patill revealed that open dumping had the greatest environmental impact. Pyrolysis-gasification with energy recovery potential and composting is an environmentally favorable MSW management option (39). Fernández-Nava et al reported that their results suggested that biomethanization of the supply-separated natural fraction, sorting of the combined fraction, and incineration of the rejected fraction had the least effect on the analyzed harm categories. At the same time, eventualities together with landfilling produced the finest effect in all of the categories analyzed. Concerning the methods involved in the studied eventualities, delivery produced a big effect within the environment, biomethanization contributed to lowering the impact of all damage categories, and incineration adversely impacted human health and weather exchange, but allowed harm to be reduced inside the assets category (40). Yay explained that, while landfilling and incineration have been confirmed as the worst waste final disposal options, composting and fabric restoration had better performances. The device (MRF, composting, incineration, and landfilling) was taken into consideration as an answer towards advanced sustainability to overcome the existing waste management

Table 2. Comparison of scenarios in terms of energy consumption

\begin{tabular}{|c|c|c|c|c|c|c|c|c|}
\hline & Recycling & Composting & EFW & Landfill & $\begin{array}{c}\text { Total waste } \\
\text { management system }\end{array}$ & $\begin{array}{c}\text { Virgin material } \\
\text { displacement system }\end{array}$ & $\begin{array}{l}\text { Reprocessing of } \\
\text { recycled materials }\end{array}$ & $\begin{array}{c}\text { Net life cycle } \\
\text { inventory }\end{array}$ \\
\hline Scenario 1 & 0 & 0 & 0 & 6853 & 6853 & 0 & 0 & 6853 \\
\hline Scenario 2 & 6844 & 4861 & 0 & 4737 & 16443 & -42241 & 29844 & 4046 \\
\hline Scenario 3 & 4111 & 9722 & 0 & 4286 & 18119 & -31945 & 11545 & -2281 \\
\hline Scenario 4 & 4111 & 9722 & 50937 & 3300 & 33804 & -64959 & 11545 & -19610 \\
\hline
\end{tabular}

Abbreviation: EFW, energy from waste.

Table 3. Comparison of scenarios in terms of environmental emissions

\begin{tabular}{|c|c|c|c|c|c|}
\hline Environmental emissions & & Scenario1 & Scenario 2 & Scenario 3 & Scenario 4 \\
\hline \multirow{3}{*}{ Greenhouse Gases } & $\mathrm{CO}_{2}$ (tones) & 511 & -23240 & -18581 & -6434 \\
\hline & $\mathrm{CH}_{4}+\mathrm{NO}_{\mathrm{x}}$ (tones) & 7161 & 4822 & 4656 & 3367 \\
\hline & CO2 Equivalents (tones) & 151549 & 56591 & 64931 & 56595 \\
\hline \multirow{3}{*}{ Acid Gases } & $\mathrm{NO}_{x}$ (tones) & 2.3 & -74.1 & -49.3 & -26.6 \\
\hline & $\mathrm{SO}_{x}$ (tones) & 1.7 & -11.4 & -103.8 & -97 \\
\hline & $\mathrm{HCl}$ (tones) & 0.6 & -677.2 & -919.4 & -916.2 \\
\hline \multirow{3}{*}{ Smog Precursors } & $\mathrm{NO}_{x}$ (tones) & 2.3 & -74.1 & -49.3 & -26.6 \\
\hline & PM (tones) & 39.1 & 10.6 & 29.4 & 23.7 \\
\hline & VOCs (tones) & 22.8 & -13.5 & 16.4 & 14.4 \\
\hline \multicolumn{6}{|l|}{ Heavy Metals \& Organics } \\
\hline \multirow{4}{*}{ Air } & $\mathrm{Pb}(\mathrm{kg})$ & 0.1 & -4.6 & -4.8 & 12.5 \\
\hline & $\mathrm{Hg}(\mathrm{kg})$ & 0 & 0 & 0 & 6.58 \\
\hline & $\mathrm{Cd}(\mathrm{kg})$ & 0.07 & 0.02 & 0 & 1.71 \\
\hline & Dioxins (TEQ) (g) & 0.003 & 0.002 & 0.002 & 0.019 \\
\hline \multirow{5}{*}{ Water } & $\mathrm{Pb}(\mathrm{kg})$ & 6.72 & -10.75 & -17.05 & -18.38 \\
\hline & $\mathrm{Hg}(\mathrm{kg})$ & 0.092 & 0.067 & 0.059 & 0.036 \\
\hline & $\mathrm{Cd}(\mathrm{kg})$ & 9.311 & 6.293 & 5.224 & 3.589 \\
\hline & $\mathrm{BOD}(\mathrm{kg})$ & 123727 & 93615 & 77713 & 56986 \\
\hline & Dioxins (TEQ) (g) & 0.00124 & 0.00090 & 0.00078 & 0.00056 \\
\hline Residual Waste (tones) & & 143451 & 101701 & 90113 & 64925 \\
\hline
\end{tabular}


trouble. The paper showed LCA to be a treasured tool that can assist governors and managers in planning an IWM approach that provides more preferable environmental outcomes than the strategy suggested (8). To protect the plant environment and conserve natural resources, there is an obligation for the network to decrease waste output and recycle as much waste as possible. The restoration of solid waste is economically and environmentally worthwhile. In preference to landfilling substances such as glass, plastic, metal, ceramic, and paper, they can be assessed as secondary uncooked substances. Hence, it is viable to properly decrease the need for uncooked fabric and lower the energy intake for raw material production of an enterprise. The recuperation of stable waste will even reduce the amount of landfilling. Mixing the life cycle analysis and multicriteria decision-making can assist environmental designers in making better decisions regarding one-of-a-kind waste scenarios. In this investigation, waste management alternatives were examined from environmental and economic points of view. The results might be supported with other decisionmaking tools that consider the social effects of solid waste management. In accordance with the results of this study, Scenario 4 (source separation [14\%] + composting [30\%] + municipal recycling facility $[\mathrm{MRF}](20 \%)+$ energy recovery $[10 \%]+$ landfilling $[26 \%]$ ) was found to be the option with the minimum environmental impact. In the absence of governmental support and sufficient funds for establishing energy recovery facilities, Scenario 3 (source separation $[14 \%]+$ composting [30\%] + MRF [20\%] + landfilling [36\%]) is recommended.

\section{Conclusion}

This study assessed the life cycle of the current system of waste management in Tehran Municipality Region 20. Social and economic factors were not considered; therefore, the results can be considered in decisionmaking only from an environmental point of view. Economic (fuel costs), social (increased respiratory diseases, etc), and psychological (abnormal noises from the collection and transportation of waste) factors must be combined with environmental factors in evaluation and decision-making. The results of this study showed that a complete picture can be a LCA of a MSWMS in terms of the environment and also serve as a valuable tool in the hands of decision-makers. The results of the current study indicated recycling is one of the best alternatives for waste control. Furthermore, composting has a crucial position in alleviating the burden of pollutants and electricity usage in a waste control system. The results regarding the current status of the waste management system in Tehran Municipality Region 20 are accurate. Therefore, likely the results of this study due to the different characteristics of the waste, technology factors, times and places differ whit previous studies.

\section{Acknowledgments}

The authors would like to thank the Research Vice
Chancellor of Shahid Sadoughi University of Medical Sciences.

\section{Ethical issues}

The authors declare that all the data collected during the present study is published in this work, and there are no ethical issues in this work.

\section{Competing interests}

The authors declare that they have no competing interests.

\section{Authors' contributions}

SO, ZD, ZG and MM performed data collection, carried out statistical and technical analysis of data, participated in design of study and drafted manuscript. MM and ZD participated in the final version of manuscript and intellectual helping for analyzing of data. All authors read and approved the final manuscript.

\section{References}

1. Özeler D, Yetiş U, Demirer GN. Life cycle assesment of municipal solid waste management methods: Ankara case study. Environ Int 2006; 32(3): 405-11. doi: 10.1016/j. envint.2005.10.002.

2. Arena U, Ardolino F, Di Gregorio F. A life cycle assessment of environmental performances of two combustion-and gasification-based waste-to-energy technologies. Waste Manag 2015; 41: 60-74. doi: 10.1016/j.wasman.2015.03.041.

3. ISO I. 14040: Environmental management-life cycle assessment-principles and framework. London: British Standards Institution; 2006.

4. Astrup TF, Tonini D, Turconi R, Boldrin A. Life cycle assessment of thermal waste-to-energy technologies: review and recommendations. Waste Manag 2015; 37: 10415. doi: 10.1016/j.wasman.2014.06.011.

5. Ahamed A, Yin K, Ng B, Ren F, Chang VC, Wang JY. Life cycle assessment of the present and proposed food waste management technologies from environmental and economic impact perspectives. J Clean Prod 2016; 131: 607-14. doi: 10.1016/j.jclepro.2016.04.127.

6. Stamou I, Antizar-Ladislao B. A life cycle assessment of the use of compost from contaminated biodegradable municipal solid waste with silver and titanium dioxide nanoparticles. J Clean Prod 2016; 135: 884-91. doi: 10.1016/j.jclepro.2016.06.150.

7. Piroozan P. Waste management of HDPE of Petrochemical Company in Bandar Imam with emphasis on life cycle assessment (LCA). Tehran: University of Tehran; 2008.

8. Yay ASE. Application of life cycle assessment (LCA) for municipal solid waste management: a case study of Sakarya. J Clean Prod 2015; 94: 284-93. doi: 10.1016/j. jclepro.2015.01.089.

9. Jensen AA. Life Cycle Assessment (LCA): A Guide to Approaches, Experiences and Information Sources. Copenhagen, Denmark: European Environment Agency; 1997.

10. Graedel TE, Allenby BR, Comrie PR. Pollution prevention: matrix approaches to abridged life cycle assessment. Environ Sci Technol 1995; 29(3): 134A-9A. doi: 10.1021/ es00003a751.

11. Morse GK, Perry R, Lester JN. The life-cycle environmental 
impact of key detergent builder systems in the EU. Sci Total Environ 1995; 166(1-3): 179-92.

12. Dobson ID. Life cycle assessment for painting processes: putting the VOC issue in perspective. Progress in Organic Coatings 1996; 27(1-4): 55-8. doi: 10.1016/03009440(95)00519-6.

13. Robertson JGS, Wood JR, Ralph B, Fenn R. Analysis of lead/acid battery lifecycle factors: their impact on society and the lead industry. J Power Sources 1997; 67(1-2): 22536. doi: 10.1016/S0378-7753(97)02554-8.

14. Sombekke HDM, Voorhoeve DK, Hiemstra P. Environmental impact assessment of groundwater treatment with nano-filtration. Desalination 1997; 113(23): 293-6. doi: 10.1016/S0011-9164(97)00144-6.

15. Berg S. Some aspects of LCA in the analysis of forestry operations. J Clean Prod 1997; 5(3): 211-7. doi: 10.1016/ S0959-6526(97)00040-1.

16. Rieradevall J, Domènech X, Fullana P. LCA case studies, application of life cycle assessment to landfilling. Int J Life Cycle Assess 1997; 2: 141. doi: 10.1007/BF02978806.

17. Diamond ML, Page CA, Campbell M, McKenna S, Lall R. Life-cycle framework for assessment of site remediation options: Method and generic survey. Environ Toxicol Chem 1999; 18(4): 788-800. doi: 10.1002/etc.5620180427.

18. Abduli MA, Naghib A, Younesi M, Akbari A. Life cycle assessment of solid waste management strategies in Tehran: landfill and composting plus landfill. J Environ Monit Assess 2009; 178(1-4): 487-98. doi: 10.1007/s10661-0101707-x.

19. Alavi Moghadam MA, Mokhtarani N, Mokhtarani B. Municipal solid waste management in Rasht city, Iran. Waste Manag 2009; 29(1): 485-9. doi: 10.1016/j. wasman.2008.02.029.

20. Ghiasinejad H, Abduli S. Technical and economical selection of optimum transfer-transport method in solid waste management in metropolitan cities. Int J Environ Res Public Health 2007; 1(2): 179-87.

21. Jalili Ghazi Zade M, Noori R. Prediction of municipal solid waste generation by use of artificial neural network: a case study of Mashhad. Int J Environ Res 2008; 2(1): 13-22.

22. Damghani AM, Savarypour G, Zand E, Deihimfard R. Municipal solid waste management in Tehran: current practices, opportunities and challenges. Waste Manag 2008; 28(5): 929-34. doi: 10.1016/j.wasman.2007.06.010.

23. Sadugh MB, Jalili Ghazizadeh $M$, Pezeshk $H$, Jalili Ghazizadeh V. Evaluating the recovery potential of solid wastes. Int J Environ Res 2009; 3(4): 681-90.

24. Ghanbarzadeh Lak M, Sabour M. Life cycle assessment of municipal solid waste disposal scenarios in aspect of greenhouse gases and energy consumption: a case study of Siri Island. Journal of Environmental Studies 2010; 36(55): 67-78. [In Persian].

25. Rafie R, Salman Mahini A, Khorasani N. Environmental life cycle assessment of municipal solid waste management system (case study: Mashad city). J Agric Nat Res 2009; 16(Special Issue 2): 208-220. [In Persian].

26. Aprili PG, Bergonzoni M, Buttol P, Cecchini F, Neri P.
Life cycle assessment of a municipal solid waste landfill. Proceedings Sardinia 99. Cagliari, Italy: CISA; 1999.

27. Banar M, Cokaygil Z, Ozkan A. Life cycle assessment of solid waste management options for Eskisehir Turkey. Waste Manag 2009; 29(1): 54-62. doi: 10.1016/j. wasman.2007.12.006.

28. Barlaz M, Camobreco V, Repa E, Ham R, Felker M, Rousseau C, et al. Life cycle inventory of a modern municipal solid waste landfill. Waste Manag Res 1999; 17(6): 394-408. doi: 10.1034/j.1399-3070.1999.00079.x.

29. Barton JR, Dalley D, Patel VS. Life cycle assessment for waste management. Waste Manag 1996; 16(1-3): 35-50.

30. den Boer J, den Boer E, Jager J. LCA-IWM: a decision support tool for sustainability assessment of waste management systems. Waste Manag 2007; 27(8): 1032-45. doi: $\quad$ 10.1016/j.wasman.2007.02.022.

31. Buttol P, Masoni P, Bonoli A, Goldoni S, Belladonna V, Cavazzuti C. LCA of integrated MSW management systems: case study of the Bologna district. Waste Manag 2007; 27(8): 1059-70. doi: 10.1016/j.wasman.2007.02.010.

32. Cherubini F, Bargigli S, Ulgiati S. Life cycle assessment (LCA) of waste management strategies: landfilling, sorting plant and incineration. Energy 2009; 34(12): 2116-23. doi: 10.1016/j.energy.2008.08.023.

33. Hong J, Li X, Zhaojie C. Life cycle assessment of four municipal solid waste management scenarios in China. Waste Manag 2010; 30(11): 2362-9. doi: 10.1016/j. wasman.2010.03.038.

34. Mendes M, Aramaki T, Hanaki K. Comparison of the environmental impact incineration and landfilling in São Paulo City as determined by LCA. Resources, Conservation and Recycling 2004; 41(1): 47-63. doi: 10.1016/j. resconrec.2003.08.003.

35. Obersteiner G, Binner E, Mostbauer P, Salhofer S. Landfill modeling in LCA - a contribution based on empirical data. Waste Manag 2007; 27(8): S58-74. doi: 10.1016/j. wasman.2007.02.018.

36. Schwing E, Jager J. Comparison of waste treatment systems by means of LCA: methodology and consequences. Cagliari Italy: CISA; 1999.

37. Dehghani MH, Dehghanifard E, Azam K, Asgari A, Baneshi MM. A quantitative and qualitative investigation of Tehran solid waste recycling potential. Journal of Knowledge \& Health 2009; 4(1): 40-4. [In Persian].

38. Doughall M. Integrated waste management model for municipalities. 2004. Available from: https://uwaterloo.ca/ integrated-waste-management-model-for-municipalities/. Accessed May 26, 2016.

39. Mali ST, Patil SS, eds. Life-cycle assessment of municipal solid waste management. Waste and Resource Management 2016; 169(4): 181-90. doi: 10.1680/jwarm.16.00013.

40. Fernández-Nava Y, Del Rio J, Rodríguez-Iglesias J, Castrillón L, Marañón E. Life cycle assessment of different municipal solid waste management options: a case study of Asturias (Spain). J Clean Prod 2014; 81: 178-89. doi: 10.1016/j.jclepro.2014.06.008. 